\title{
Effects of Warm Winter Temperature on the Abundance and Gonotrophic Activity of Culex (Diptera: Culicidae) in California
}

\author{
WILLIAM K. REISEN ${ }^{1}$, TARA THIEMANN, CHRISTOPHER M. BARKER, HELEN LU, BRIAN \\ CARROLL, YING FANG, and HUGH D. LOTHROP \\ Center for Vectorborne Diseases, Department of Pathology, Microbiology and Immunology, School \\ of Veterinary Medicine, University of California, Old Davis Road, Davis, CA 95616
}

\begin{abstract}
Culex tarsalis Coquillett, $C x$. quinquefasciatus Say, and $C x$. pipiens $\mathrm{L}$. were collected during the warm winter of 2009 using dry ice-baited and gravid traps and walk-in red boxes positioned in desert, urban, and agricultural habitats in Riverside, Los Angeles, Kern, and Yolo Counties. Temperatures exceeded the preceding $50 \mathrm{yr}$ averages in all locations for most of January, whereas rainfall was absent or below average. Abundance of Culex species in traps during January ranged from 83 to $671 \%$ of the prior $5 \mathrm{yr}$ average in all locations. Few females collected resting were in diapause during January based on follicular measurements. Evidence for early season gonotrophic activity included the detection of freshly bloodfed, gravid, and parous females in resting collections, gravid oviposition site-seeking females in gravid female traps, and nulliparous and parous host-seeking females at dry ice-baited traps. Female Culex seemed to employ multiple overwintering strategies in California, including larval and adult quiescence, adult female diapause, and an intermediate situation with adult females collected with enlarged follicles, but without evident vitellogenesis. West Nile, St. Louis, or western equine encephalitis viruses were not detected in 198 pools of adults or 56 pools of adults reared from field-collected immatures collected during January and February 2009. Our preliminary data may provide insight into how climate change may extend the mosquito season in California.
\end{abstract}

\section{Keywords}

Culex; diapause; overwintering; California

\begin{abstract}
In California, the initiation of gonotrophic activity by Culex mosquitoes during winter or early spring establishes subsequent phenology and determines the earliest date for potential mosquito-borne encephalitis virus transmission, regardless of the viral overwintering mechanism(s) (Reisen et al. 2006a). Warm winters were positively correlated with subsequent increases in vernal mosquito abundance (Reisen et al. 2008a) and perhaps summer West Nile virus (Flaviviridae, Flavivirus, WNV) activity (Reisen et al. 2006b). Historical in-depth studies of winter Culex tarsalis Coquillett populations collected resting from privies and bridges in Kern County, CA, found that although blood feeding terminated in December, blood engorged females could be collected again as soon as mid-January (Bellamy and Reeves 1963) and that these females fed mostly on passerine birds (Tempelis et al. 1965). During autumn, female populations bifurcated into gonotrophically inactive nullipars that entered diapause and gonotrophically active pars that died-out by December; parity remained low through January and then increased again in February, which coincided with an increase in the numbers of females collected host-seeking at dry ice-baited traps (Nelson 1964). Based on morphology
\end{abstract}

\footnotetext{
${ }^{1}$ Coressponding author, arbo123@pacbell.net.
} 
and measurements of the primary and secondary follicles, $C x$. tarsalis females emerging after the autumnal equinox appeared to enter reproductive diapause (Reisen et al. 1986b, 1995b) in response to the fourth-instar larvae being exposed to short photoperiods and cool water temperatures (Reisen 1986). In Kern County, these overwintering females remained metabolically active, feeding on fructose and repopulating hibernacula after removal sampling, thereby implying continued flight activity (Reisen et al. 1986c). In Coachella and Imperial Valleys, females were collected host-seeking throughout winter, although there was a significant decline in both abundance and parity during December (Reisen et al. 1995a).

Less is known about the $C x$. pipienscomplex. Studies in Kern County indicated that although adult $C$. quin-quefasciatus Say females persisted into winter, they remained gonotrophically active and then disappeared after the first frost, when most of the population was in the larval stage (Reisen et al. 1986b). In Los Angeles, females remained gonotrophically active in warm underground drainage systems ( $\mathrm{Su}$ et al. 2003) or underwent quiescence during cool temperatures; gravid females were collected throughout winter in gravid female traps. At cold northern latitudes, $C x$. pipiens L. presumably entered diapause, as has been described in the eastern U.S. (Spielman 2001, Spielman and Wong 1973) and Oregon (Eldridge 1987).

California presents a unique N-S latitudinal gradient, extending from the hot dry desert biomes near Mexico through the cool wet rain forests of the coastal region near Oregon. The $C$. pipiens complex consists of at least two subspecies, pipiens L. in the north and quinquefasciatus Say south of Tehachapi Mountains, with hybrids found throughout the Central Valley (Urbanelli et al. 1997, McAbee et al. 2008). Cx. tarsalis populations also seem genetically distinct north and south of these mountains (Venkatesan et al. 2007), but the ecological significance of these genetic differences has not been established. The current study describes the phenology of reproductive onset by Culex mosquitoes, including $C x$. tarsalis and members of the $C x$. pipiens complex, during the exceptionally warm January of 2009. Our overall aim was to understand the impact of these temperatures on overwintering Culex populations within four biomes that transect southern to central California. These data may provide preliminary insight into the impact of warming climate on the winter biology of Culex.

\section{Materials and Methods}

\section{Study Areas}

Mosquitoes were collected at our established study areas in Coachella Valley (Reisen et al. 2008b), Los Angeles basin (O’Connor et al. 2007), southern San Joaquin Valley near Bakersfield (Reisen et al. 2009a) and Yolo County near Davis (Reisen et al. 2009b). Daily weather measurements during the January through February 2009 period were gathered from the nearest weather stations available and downloaded from the University of California Integrated Pest Management Website (http://www.ipm.ucdavis.edu). Maximum-minimum temperature and precipitation data were compared daily to a preceding 50-yr mean calculated for $1959-2008$ from data at the same weather stations.

\section{Mosquito Collection}

Our sampling plan varied because of collection success at different study areas. Female mosquitoes were collected at 2-20 dry ice-baited Centers for Disease Control and Prevention (CDC) style traps (Newhouse et al. 1966) operated from 1 to 3 times per week. Multiple gravid female traps (Cummings 1992) and walk-in red boxes (Meyer 1987) were sampled weekly to collect ovipositing and resting female mosquitoes, respectively. In Coachella Valley, Culex larvae were collected from 7 November 2008 through 16 February 2009, reared to adults in an insectary $\left(24 \pm 2^{\circ} \mathrm{C}, 14 \mathrm{~L}: 10 \mathrm{D}\right.$ summer photoperiod), held for $2-5 \mathrm{~d}$, identified to species and sex, enumerated into pools of $\leq 50$ individuals each, and frozen at $-80^{\circ} \mathrm{C}$ for later testing for 
virus. Females not dissected, the bodies from some dissected females (see below) and adults reared from field-collected larvae and pupae were tested for West Nile (Flaviviridae,

Flavivirus, WNV), St Louis encephalitis (Flaviviridae, Flavivirus, SLEV) and western equine encephalomyelitis (Togaviridae, Alphavirus, WEEV) virus RNA by multiplex real timepolymerase chain reaction (RT-PCR) (Shi et al. 2001) using previously published primers (Lanciotti et al. 2000). Pools positive for RNA using primers from genes encoding for the viral envelope were retested for RNA using primers from the nonstructural region and by plaque assay using Vero cells after passage in C6/36 cells.

\section{Mosquito Dissection}

Mosquitoes collected at Davis were anesthetized with triethylamine, enumerated by species, sex, and gonotrophic status, and then dissected immediately or after overnight storage at $4{ }^{\circ} \mathrm{C}$. Specimens from the remaining sites were enumerated by species and stored at $-80^{\circ} \mathrm{C}$ until thawed and then dissected. Trophic status was scored as unfed, bloodfed, or gravid, and ovarian maturation scored as stages I-V (Christophers 1911) as modified for Culex (Kawai 1969, Clements and Boocock 1984). Parity in females with ovarian development at $\leq$ stage IIa was determined for one ovary using the degree of tracheal coiling, while the second ovary was disrupted and examined for the presence of dilatations on the ovarian pedicel (Detinova 1962, Nelson 1966). Percent parous was calculated as the total of parous females (determined by either the ovarian tracheation and/or dilatation methods) divided by the total dissected, with 95\% confidence intervals (CIs) determined from the binomial distribution by the Wilson method (Agresti and Coull 2009). For unfed resting females collected in red boxes, five representative primary and secondary follicles were measured per female at $400 \times$ by an ocular micrometer (Reisen et al. 1995b). The mean of the ratio of primary over secondary follicle length was used to ascertain the diapause status of each resting female, with females with ratios $<1.5$ considered to be in diapause stage I (Reisen et al. 1986a).

\section{Results \\ Weather}

Unseasonably warm daily maximum temperatures ranged from 5 to $10^{\circ} \mathrm{C}$ above normal throughout California from 9 to 10 through 21-23 January 2009 (Fig. 1). Interestingly, these temperature anomalies included above-normal minimum temperatures in Coachella Valley and Los Angeles, but below-normal minimum temperatures in Kern and Davis within the Central Valley. The January warming period was accompanied by drought conditions, with monthly totals of 0, 8.1, 19.0, and $28.7 \mathrm{~mm}$ of rainfall recorded at Mecca, Santa Ana, Bakersfield, and Davis weather stations that were $0,27,31$, and $28 \%$ of normal January totals, respectively. Apparently, the drought in the Central Valley reduced humidity and enabled the large daily temperature ranges. In Coachella Valley where conditions are typically very dry, daily temperature changes of $15^{\circ} \mathrm{C}$ were common (Fig. 1).

\section{Mosquito Abundance and Reproductive Activity}

Culex abundance host-seeking at dry ice-baited and seeking oviposition sites at gravid female traps during January ranged from 83 to $671 \%$ of the previous 5-yr means (Table 1).

Coachella Valley-Overall, 2,771 adult $C x$. tarsalis were reared from immatures collected in the at duck marshes near the Salton Sea during the January through February 2009 period. Therefore, the high abundance of $C x$. tarsalis host-seeking in the rural southern Coachella Valley during January (Table 1) may have represented a cohort that terminated diapause (Reisen et al. 1995b) and/or emerged from overwintering immatures (Fig. 2) during late December/early January. Cx. tarsalis abundance peaked during week 4, closely after the January warm period (Fig. 1A). We dissected a representative subsample of $20-25$ females 
from each weekly $\mathrm{CO}_{2}$ trap collection. Characteristic of a single maturing cohort, the proportion of parous females increased progressively from $11 \%$ during week 2 to $92 \%$ during week 6 when abundance declined dramatically to 50 females per trap night (Fig. 2). Of the 156 females dissected, only two of 78 parous females collected during the January through February period were 2-parous, agreeing with our previous studies that indicated few females survived more than a single gonotrophic cycle even during the cooler winter months (Reisen et al. 1995a). In addition, 968 adult $C x$. quinquefasciatus were reared from immatures collected from swimming pools in the Palm Springs area during November through December 2008. Although comparatively few $C x$. quinquefasciatus were collected in gravid traps in the urban northern valley (mean $=3$ per trap-night), catch size averaged $671 \%$ above the preceding $5 \mathrm{yr}$ average.

Los Angeles-Highly urbanized Los Angeles typically supports few $C x$. tarsalis and it was difficult to collect large numbers during the current investigation (Table 1). All Cx. tarsalis females that were collected by dry ice-baited traps during January were nulliparous indicating that nondiapausing adult females may not persist through winter. This cohort seemed to age, because three of six females collected during February were parous. In contrast, large numbers of $C x$. quinquefasciatus apparently quiesced during cool periods, resting in the vast underground drainage system where temperatures remained warm throughout winter ( $\mathrm{Su}$ et al. 2003). When night temperatures permitted activity, females were collected frequently attempting to oviposit at gravid female traps (Table 1). The warm January period resulted in a Cx. quinquefasciatus gravid female catch size that averaged $257 \%$ of the previous $5 \mathrm{yr}$ average.

Kern County-Although maximum daily temperatures were above-normal, low nighttime temperatures may have limited $C x$. tarsalis flight activity and few females were collected either resting in red boxes or host seeking at $\mathrm{CO}_{2}$ traps (Table 1). Those that were collected were reproductively active, but a low percentage were parous. $C x$. quinquefasciatus females also were not abundant at this time, agreeing with previous studies (Reisen et al. 1986b) that suggested this species typically dies-out during winter.

Sacramento and Yolo Counties, Including Davis-Above-normal temperatures produced early season reproductive activity by $C x$. tarsalis in Sacramento and Yolo Counties, because host-seeking parous females were present in a composite sample from Sacramento County collected on 14 January 2009 (Table 1). Near Davis, 280 Cx. tarsalis females were collected resting in a red box at a farmstead, but only 13 were taken by $\mathrm{CO}_{2}$ traps there and none were collected by $\mathrm{CO}_{2}$ traps at the nearby Yolo bypass wetlands; 12 of 13 of these trapped females were taken during weeks 5 and 6 . Of the 280 females collected resting, 100 were unfed, 137 were bloodfed and 33 were gravid. A total of 110 females were dissected and their follicles measured to determine diapause status. Although the mean $1{ }^{\circ} 2^{\circ}$ follicular ratios for all weekly samples averaged $>1.5,16$ females collected during weeks 3 and 4 had ratios $<1.5$ and were considered to be in diapause stage I (Reisen et al. 1986a). These females consisted of 21 and $23 \%$ of those unfed females measured during weeks 3 and 4; after week 4, none were in diapause stage I. Overall, 261 resting females were scored for parity status, of which 180 were nulliparous, 77 were one-parous, and one was biparous. The single bipar was collected during week 3 and presumably was a survivor from the previous year. Similar to the cohort terminating diapause in Coachella Valley (Fig. 2), parity was initially low at $8 \%$ during week 3 and then progressively increased to a maximum of $66 \%$ by week 7 , after which the number collected and the parity rate decreased (Fig. 3). Interestingly, the number collected per red box per day rebounded to 63 during week 11 . The number of females per sample remained fairly consistent from weeks $4-7$, although the cohort progressively aged as indicated by percent parous and the proportion of gravid females (not shown). Only $27 \mathrm{Cx}$. pipiens were collected: 26 resting and one by $\mathrm{CO}_{2}$ trap. Similar to $C x$. tarsalis, 15 , eight and three of these were empty, bloodfed and gravid, respectively, and $33 \%$ of 21 dissected were uniparous. 
Arbovirus Infection-Overall, none of 198 pools comprised of 7,515 mosquitoes collected as adults during January through February 2009 were positive for WNV, WEEV, SLEV RNA by real time RT-PCR; most were tested during January (Table 1). In addition, none of 21 pools of $C x$. quinquefasciatus or 56 pools of $C x$. tarsalis that were collected as immatures in Coachella Valley and reared to adults were positive for WNV RNA and/or infectious virus. Two pools of $C x$. tarsalis initially positive for RNA by our screening assay could not be confirmed by RT-PCR or tissue culture and were considered negative.

\section{Discussion}

Warm winter temperatures were associated with early gonotrophic activity and increased abundance of Culex females in January in southern and central California. Evidence included the detection of freshly bloodfed, gravid and parous females in resting collections, gravid oviposition site-seeking females in gravid female traps, and nulliparous and parous females host-seeking at $\mathrm{CO}_{2}$ traps. Although most unfed resting females had terminated diapause (i.e., follicular ratios were $>1.5$ ), the $1^{\circ}$ follicles in many did not have visible yolk (ovariole stage I) and therefore fell into our intermediate diapause stage II (Reisen et al. 1986a). A low percentage of resting females collected during weeks 3 and 4 had ratios $<1.5$ and were considered to still be in diapause stage I; by week 5 all unfed females had follicular ratios $>1.5$ and had initiated vitellogenesis.

The current observations supported earlier studies in Kern County (Reisen et al. 1986b) and Coachella Valley (Reisen et al. 1995b) that indicated reproductive diapause was terminated at the winter solstice as evidenced by a subsequent increase in the $1 \% 2^{\circ}$ follicular ratio as the primary follicle enlarged and vitel-logenesis was initiated (Spielman et al. 1971, Mitchell 1981, Eldridge 1987). After this transition occurred, the initiation of host-seeking activity seemed linked to temperature (Bennington et al. 1958) and apparently varied with latitude (Eldridge 1987). At the warm latitudes of the Coachella Valley, host-seeking commenced in late-December (Reisen et al. 1995b), whereas host-seeking was later for the remainder of California. At the range of latitudes from Coachella Valley north to Davis, female $C x$. tarsalis and Cx. pipiens complex mosquitoes terminated diapause and were host-seeking, reproductively active, and parous by early January 2009. Collection of parous Culex in the Central Valley during January was novel and attributable to the exceptionally warm winter temperatures in 2009. In addition, these mild temperatures may have allowed biparous females to survive from 2008 into January 2009. It is also interesting that large numbers of $C x$. tarsalis larvae were found during winter at duck marshes in Coachella Valley, which indicated that the January through February host-seeking population probably included some adults that emerged from these larvae. Although it is unknown whether $C x$. tarsalis overwinters extensively as slowly developing larvae elsewhere in California, larvae have been collected previously during winter in Kern County (Washino and Bellamy 1963) and we collected several males resting in red boxes at Davis during the current study.

In summary, California Culex appeared to use a complex assemblage of overwintering mechanisms that seemed necessary to accommodate latitudinal and temporal variation in climate. These mechanisms included:

1. Quiescence. Adult and immature $C x$. quinquefasciatus and immature $C x$. tarsalis at southern latitudes appeared to become inactive during cold periods, but immediately renewed their feeding and development during warm periods, when temperatures exceeded the $5-10^{\circ} \mathrm{C}$ threshold estimated for development from degree-day models (Reisen 1995). In the Central Valley, adult Cx. quinquefasciatus may not be able to tolerate prolonged freezing conditions and overwintered as immatures, because adults have never been collected in diapause. 
2. Reproductive diapause. Fourth-instar $C x$. tarsalis (and presumably $C x$. pipiens [Eldridge 1968]) exposed to cool temperature and short day length gave rise to females with primary follicles arrested at stage I and with $1 \% 2^{\circ}$ follicular ratios $<1.5$ (Reisen 1986). In California these females do not blood feed but remain vagile and metabolically active, repopulating resting sites after removal sampling (Bellamy and Reeves 1963) and imbibing fructose (Reisen et al. 1986c). These females at overwintering stage I (Reisen et al. 1986a) apparently remain in diapause until after the winter solstice (Reisen et al. 1995b), after which termination seems governed by temperature (Bennington et al. 1958, Bennington and Sherman 1960).

3. Intermediate. Some females found throughout winter in resting collections previously (Reisen et al. 1986b) and in the current study were in overwintering stage II, exhibiting arrested vitellogenesis, but commencing follicular growth as evidenced by the $1 \% 2^{\circ}$ follicular ratios being $>1.5$. Overwintering stage II females were produced occasionally during diapause induction experiments with the F1 progeny of field females (Reisen et al. 1986a) and may constitute a deme that does not enter a typical stage I diapause. Possibly, these females would terminate diapause more readily than diapause stage I females.

An overwintering population made up of females in various reproductive states may explain the unexpectedly prolonged collection of nullipars and the apparent long survival of the overwintering cohort during the January through February period shown in Figs. 2 and 3. Based on previous trapping results (Nelson 1964,Reisen et al. 1986b), we had expected diapause termination in central California to be later in January, relatively synchronous, and followed by high mortality in the overwintering adults after their first oviposition. The slow increase in the parity rate (even in Coachella Valley) indicated that this overwintering cohort survived well beyond the first oviposition and took multiple bloodmeals. The staggered emergence of females from diapause and prolonged period of host-seeking and oviposition may increase the population's chance for survival by minimizing the impact of brief periods of unseasonally cold weather (diapause termination is usually associated with reduced freeze tolerance [Eldridge 1987,Mitchell 1988]) or a shortage of oviposition and larval habitat because of delayed or low winter rainfall.

Regardless of latitude, transmission of WNV and other arboviruses in California typically subsides during fall and is interrupted during winter. Virus activity typically resumes first in Coachella Valley and the southeastern deserts during April or May (Reisen et al. 2006a) and then in June or later in the remainder of the state, but has rarely been detected during the January through March period. Collectively, these data indicate that either virus does not overwinter within vertically infected adult or larval mosquitoes or that replication within the mosquito host is necessary before detection (Bailey et al. 1978). Temperatures within our California study areas during the winter of 2009 were warm enough for intermittent viral replication (Reisen et al. 2006b) and therefore viruses, if present, should have been detected using RTPCR; however, all pools were negative. On-going research continues to address possible mechanisms of WNV overwintering in California.

The current preliminary research documented early season gonotrophic activity by Culex mosquitoes from Coachella Valley through Sacramento County in response to above normal winter temperatures. Temperature driven changes in phenology may become increasingly evident at the beginning and ends of favorable seasons rather than during the middle when temperature is not limiting. With climate models predicting a $3-5^{\circ} \mathrm{C}$ increase in ambient temperatures during the next $50-100 \mathrm{yr}$ (Cayan et al. 2008), our current results may provide preliminary insight into the changing seasonality of California mosquitoes and perhaps the viruses they transmit. 


\section{Acknowledgments}

We especially thank the staff of the Coachella Valley, Greater Los Angeles County, Kern, and Sacramento-Yolo Mosquito and Vector Control Districts who assisted with winter mosquito collections and provided logistical and fiscal support. Amy Jobe assisted with field collections in Kern County and Sandra Garcia and Maureen Dannen, Center for Vectorborne Diseases, assisted with testing the mosquito pools. This research was funded, in part, by Grant RO1AI55607-06A2 from the National Institute of Allergy and Infectious Diseases using American Recovery and Reinvestment Act Support.

\section{References Cited}

Agresti A, Coull BA. Approximate is better than "Exact" for interval estimation of binomial proportions. Am Statistician 2009;52:119-126.

Bailey CL, Eldridge BF, Hayes DE, Watts DM, Tammariello RF, Dalrymple JM. Isolation of St. Louis encephalitis virus from overwintering Culex pipiens mosquitoes. Science 1978;199:1346-1349. [PubMed: 628843]

Bellamy RE, Reeves WC. The winter biology of Culex tarsalis (Diptera: Culicidae) in Kern County, California. Ann Entomol Soc Am 1963;56:314-323.

Bennington EE, Blackmore JS, Sooter CA. Soil temperatures and the emergence of Culex tarsalis from hibernation. Mosq News 1958;18:297-298.

Bennington EE I, Sherman L. A note on reported cases of encephalitis and soil temperatures in Colorado. Mosq News 1960;20:191-195.

Cayan DR, Maurer EP, Dettinger MD, Tyree M, Hayhoe K. Climate change scenarios for the California region. Climatic Change 2008;87:s21-s42.

Christophers SR. Development of the egg follicle in anophelines. Paludism 1911;2:73-89.

Clements AN, Boocock MR. Ovarian development in mosquitoes: stages of growth and arrest, and follicular resorption. Physiol Entomol 1984;9:1-8.

Cummings RF. Design and use of a modified Reiter gravid mosquito trap for mosquito-borne encephalitis surveillance in Los Angeles County, California. Proc Mosq Vector Control Assoc Calif 1992;60:170176.

Detinova TS. Age-grading methods in Diptera of medical importance. Monogr Ser World Health Organ 1962;47:1-216.

Eldridge BF. The effect of temperature and photo-period of blood feeding and ovarian development in mosquitoes of the Culex pipiens complex. Am J Trop Med Hyg 1968;17:133-140. [PubMed: 5688903]

Eldridge BF. Diapause and related phenomena in Culex mosquitoes: their relation to arbovirus disease ecology. Curr Top Vector Res 1987;4:1-28.

Kawai S. Studies on the follicular development and feeding activity of the females of Culex tritaeniorhynchus with special reference to those of autumn. Trop Med 1969;11:145-169.

Lanciotti RS, Kerst AJ, Nasci RS, Godsey MS, Mitchell CJ, Savage HM, Komar N, Panella NA, Allen BC, Volpe KE, Davis BS, Roehrig JT. Rapid detection of West Nile virus from human clinical specimens, field-collected mosquitoes, and avian samples by a TaqMan reverse transcriptase-PCR assay. J Clin Microbiol 2000;38:4066-4071. [PubMed: 11060069]

McAbee RD, Green EN, Holeman J, Christiansen J, Frye N, Dealey K, Mulligan FS III, Brault AC, Cornel AJ. Identification of Culex pipiens complex mosquitoes in a hybrid zone of West Nile virus transmission in Fresno County, California. Am J Trop Med Hyg 2008;78:303-310. [PubMed: 18256434]

Meyer RP. The "walk-in" type red box for sampling resting adult mosquitoes. Proc N J Mosq Contr Assoc 1987;72:104.

Mitchell CJ. Diapause termination, gonoactivity and differentiation of host-seeking behavior from bloodfeeding behavior in hibernating Culex tarsalis (Diptera: Culicidae). J Med Entomol 1981;18:386394.

Mitchell, CJ. Occurrence, biology and physiology of diapause in overwintering mosquitoes. In: Monath, TP., editor. The Arboviruses: Epidemiology and Ecology. CRC, Inc; Boca Raton, FL: 1988. p. 191-217. 
Nelson RL. Parity in winter populations of Culex tarsalis Coquillett in Kern County, California. Am J Hyg 1964;80:242-253. [PubMed: 14215835]

Nelson RL. A comparison of two techniques for distinguishing parous from nulliparous Culex tarsalis Coquillett. Mosq News 1966;26:11-13.

Newhouse VF, Chamberlain RW, Johnston JG Jr, Sudia WD. Use of dry ice to increase mosquito catches of the CDC miniature light trap. Mosq News 1966;26:30-35.

O'Connor P, Wilson JL, Spoehel J, Kluh S, Morales H, Madon MB. West Nile virus Foci in Greater Los Angeles County Vector Control District, 2003-2006. Proc Mosq Vector Control Assoc Calif 2007;75:14-16.

Reisen WK. Overwintering studies on Culex tarsalis (Diptera: Culicidae) in Kern County, California: life stages sensitive to diapause induction cues. Ann Entomol Soc Am 1986;79:674-676.

Reisen WK. Effect of temperature on Culex tarsalis (Diptera: Culicidae) from the Coachella and San Joaquin Valleys of California. J Med Entomol 1995;32:636-645. [PubMed: 7473618]

Reisen WK, Carroll BD, Takahashi R, Fang Y, Garcia S, Martinez VM, Quiring R. Repeated West Nile virus epidemic transmission in Kern County, California, 2004-2007. J Med Entomol 2009a;46:139_ 157. [PubMed: 19198528]

Reisen WK, Cayan D, Tyree M, Barker CM, Eldridge BF, Dettinger M. Impact of climate variation on mosquito abundance in California. J Soc Vector Ecol 2008a;33:89-98.

Reisen WK, Fang Y, Lothrop HD, Martinez VM, Wilson J, O'Connor P, Carney R, Cahoon-Young B, Shafii M, Brault AC. Overwintering of West Nile virus in Southern California. J Med Entomol 2006a; 43:344-355. [PubMed: 16619621]

Reisen WK, Fang Y, Martinez VM. Effects of temperature on the transmission of West Nile virus by Culex tarsalis (Diptera: Culicidae). J Med Entomol 2006b;43:309-317. [PubMed: 16619616]

Reisen WK, Lothrop HD, Hardy JL. Bionomics of Culex tarsalis (Diptera: Culicidae) in relation to arbovirus transmission in southeastern California. J Med Entomol 1995a;32:316-327. [PubMed: 7616523]

Reisen WK, Lothrop HD, Wheeler SS, Kensington M, Gutierrez A, Fang Y, Garcia S, Lothrop B. Persistent West Nile virus transmission and the displacement St Louis encephalitis virus in southeastern California, 2003-2006. J Med Entomol 2008b;45:494-508. [PubMed: 18533445]

Reisen WK, Meyer RP, Milby MM. Overwintering studies on Culex tarsalis (Diptera: Culicidae) in Kern County, California: survival and the experimental induction and termination of diapause. Ann Entomol Soc Am 1986a;79:664-673.

Reisen WK, Meyer RP, Milby MM. Overwintering studies on Culex tarsalis (Diptera: Culicidae) in Kern County, California: temporal changes in abundance and reproductive status with comparative observations on C. quinquefasciatus (Diptera: Culicidae). Ann Entomol Soc Am 1986b;79:677-685.

Reisen WK, Meyer RP, Milby MM. Patterns of fructose feeding by Culex tarsalis (Diptera: Culicidae). J Med Entomol 1986c;23:366-373. [PubMed: 3735340]

Reisen WK, Smith PT, Lothrop HD. Short term reproductive diapause by Culex tarsalis (Diptera: Culicidae) in the Coachella Valley of California. J Med Entomol 1995b;32:654-662. [PubMed: 7473621]

Reisen WK, Wheeler S, Armijos MV, Fang Y, Garcia S, Kelley K, Wright S. Role of communally nesting ardeid birds in the epidemiology of West Nile virus revisited. Vector Borne Zoonotic Dis 2009b; 9:275-280. [PubMed: 19125659]

Shi PY, Kauffman EB, Ren P, Felton A, Tai JH, DuPuis AP, Jones SA, Ngo KA, Nicholas DC, Maffei J, Ebel GD, Bernard KA, Kramer LD. High-throughput detection of West Nile virus RNA. J Clin Microbiol 2001;39:1264-1271. [PubMed: 11283039]

Spielman A. Structure and seasonality of nearctic Culex pipiens populations. Ann N Y Acad Sci 2001;951:220-234. [PubMed: 11797779]

Spielman A, Gwadz RW, Anderson WA. Ecdysone-initiated ovarian development in mosquitoes. J Insect Physiol 1971;17:1807-1814. [PubMed: 4398560]

Spielman A, Wong J. Environmental control of ovarian diapause in Culex pipiens. Ann Entomol Soc Am 1973;66:905-907. 
Su T, Webb JP, Meyer RP, Mulla MS. Spatial and temporal distribution of mosquitoes in underground storm drain systems in Orange County, California. J Vector Ecol 2003;28:79-89. [PubMed: 12831132]

Tempelis CH, Reeves WC, Bellamy RE, Lofy MF. A three-year study of the feeding habits of Culex tarsalis in Kern County, California. Am J Trop Med Hyg 1965;14:170-177. [PubMed: 14248992]

Urbanelli S, Silvestrini F, Reisen WK, deVito E, Bullini L. California hybrid zone between Culex pipiens pipiens and Cx. p quinquefasciatus revisited (Diptera: Culicidae). J Med Entomol 1997;34:116-127. [PubMed: 9103754]

Venkatesan M, Westbrook CJ, Hauer MC, Rasgon JL. Evidence for a population expansion in the West Nile virus vector Culex tarsalis. Mol Biol Evol 2007;24:1208-1218. [PubMed: 17339636]

Washino RK, Bellamy RE. Winter observation on larval populations of Culex tarsalis Coquillett in Kern County, California. Mosq News 1963;23:162-163. 

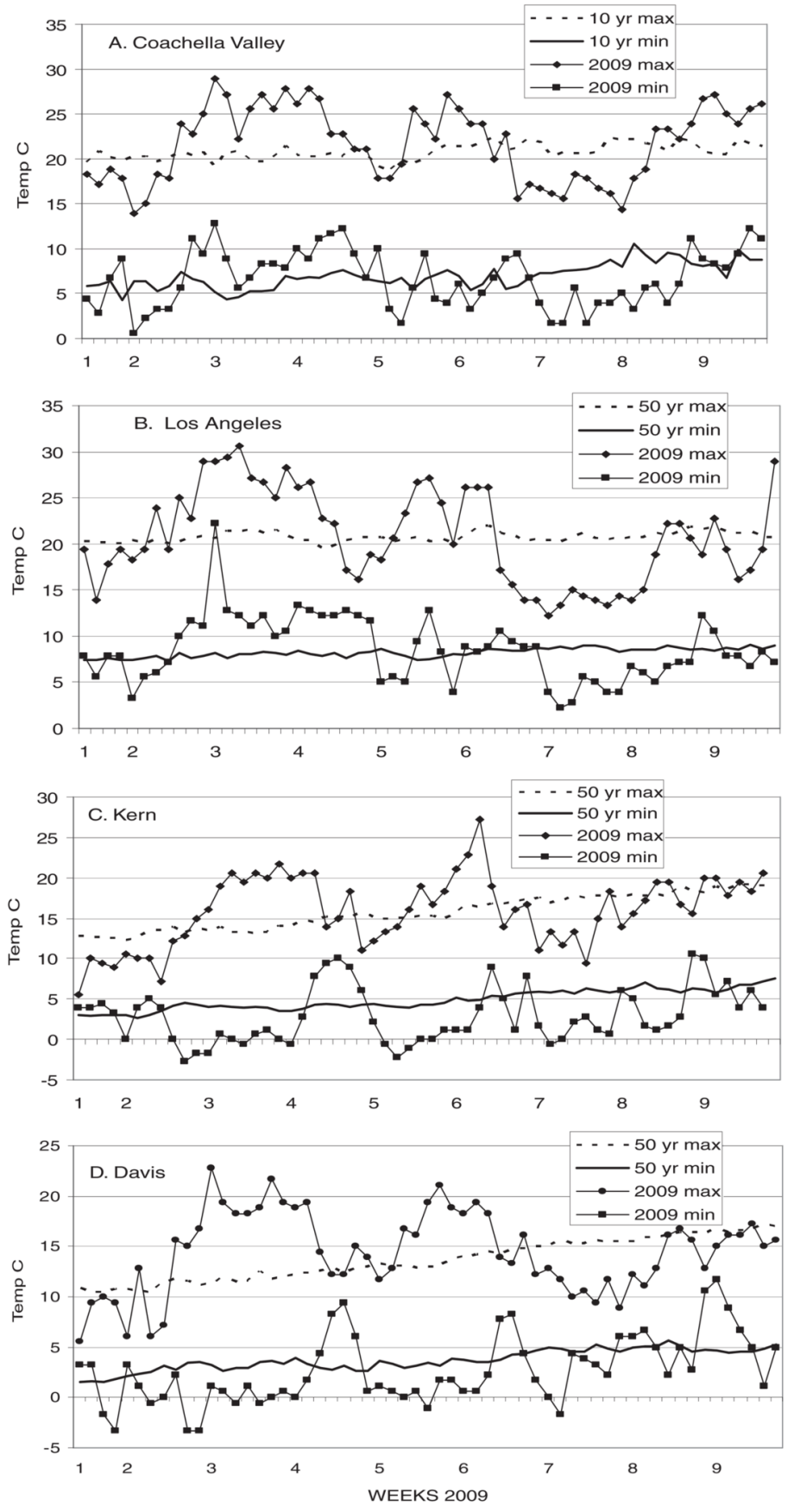

Fig. 1.

Daily maximum and minimum temperatures during 2009 compared with concurrent 10 or 50 yr averages in (A) Coachella Valley, (B) Los Angeles, (C) Kern, and (D) Davis, CA. (Online figure in color.) 


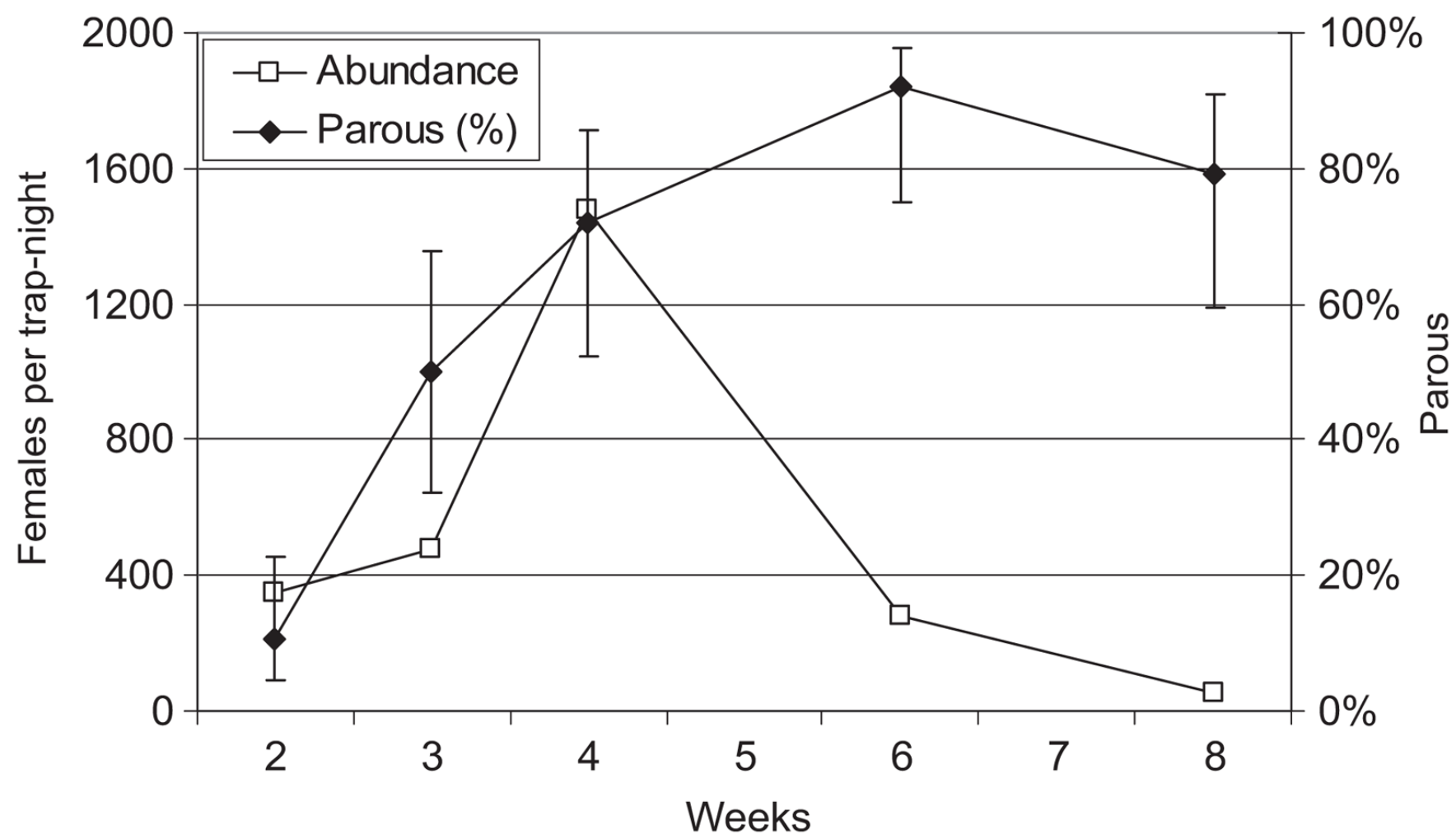

Fig. 2.

CX. tarsalis abundance (females collected per $\mathrm{CO}_{2}$ trap per night, $n=2-4$ operated per week) and percent parous with $95 \%$ CI plotted as a function of time in weeks during 2009 in Coachella Valley, Riverside County, CA. 


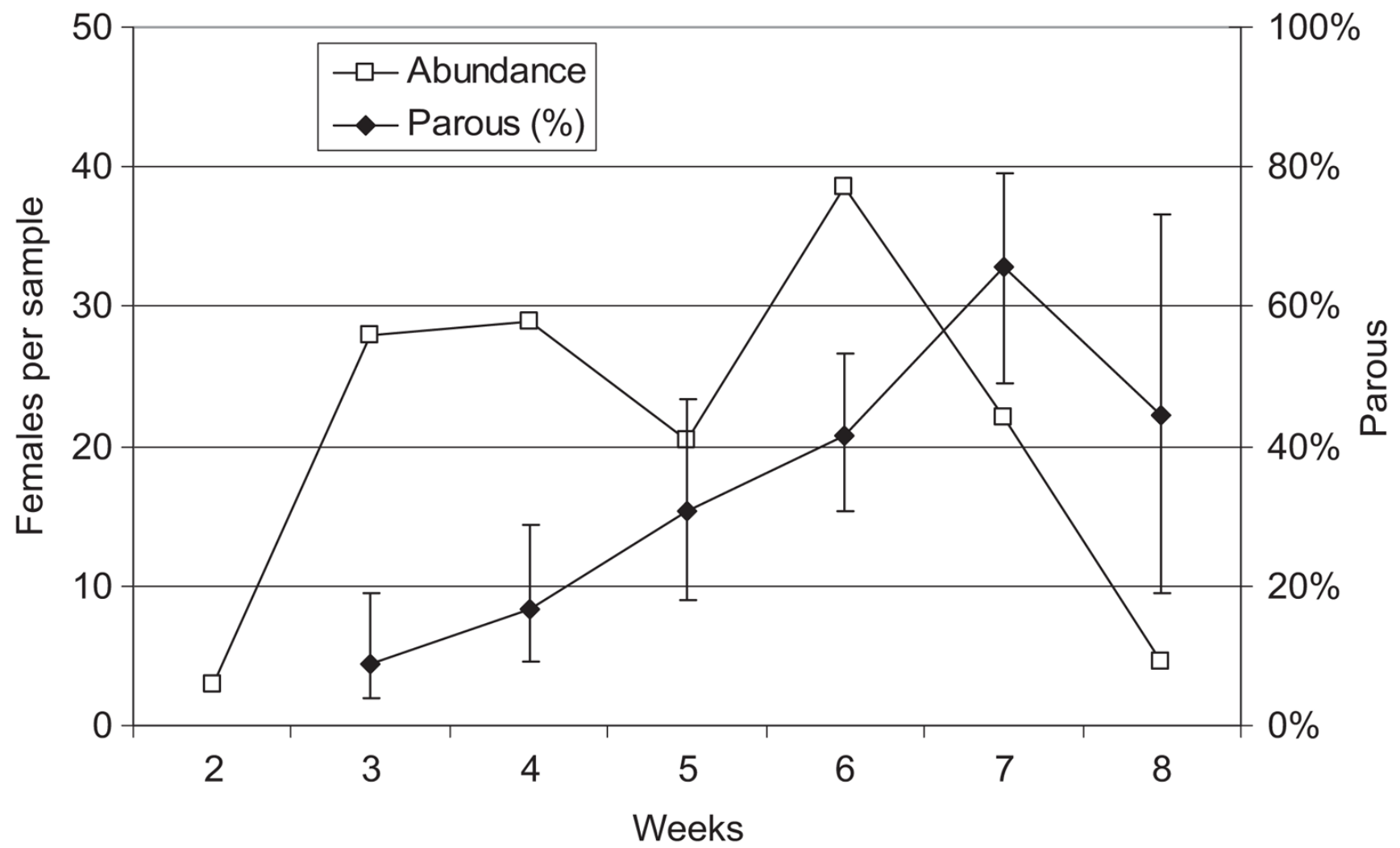

Fig. 3.

Cx. tarsalis abundance (females per walk-in red box collection, $n=1$ walk-in red box examined 2-3 times per week) and percent parous with 95\% CI plotted as a function of time in weeks during 2009 near Davis, Yolo County, CA. 


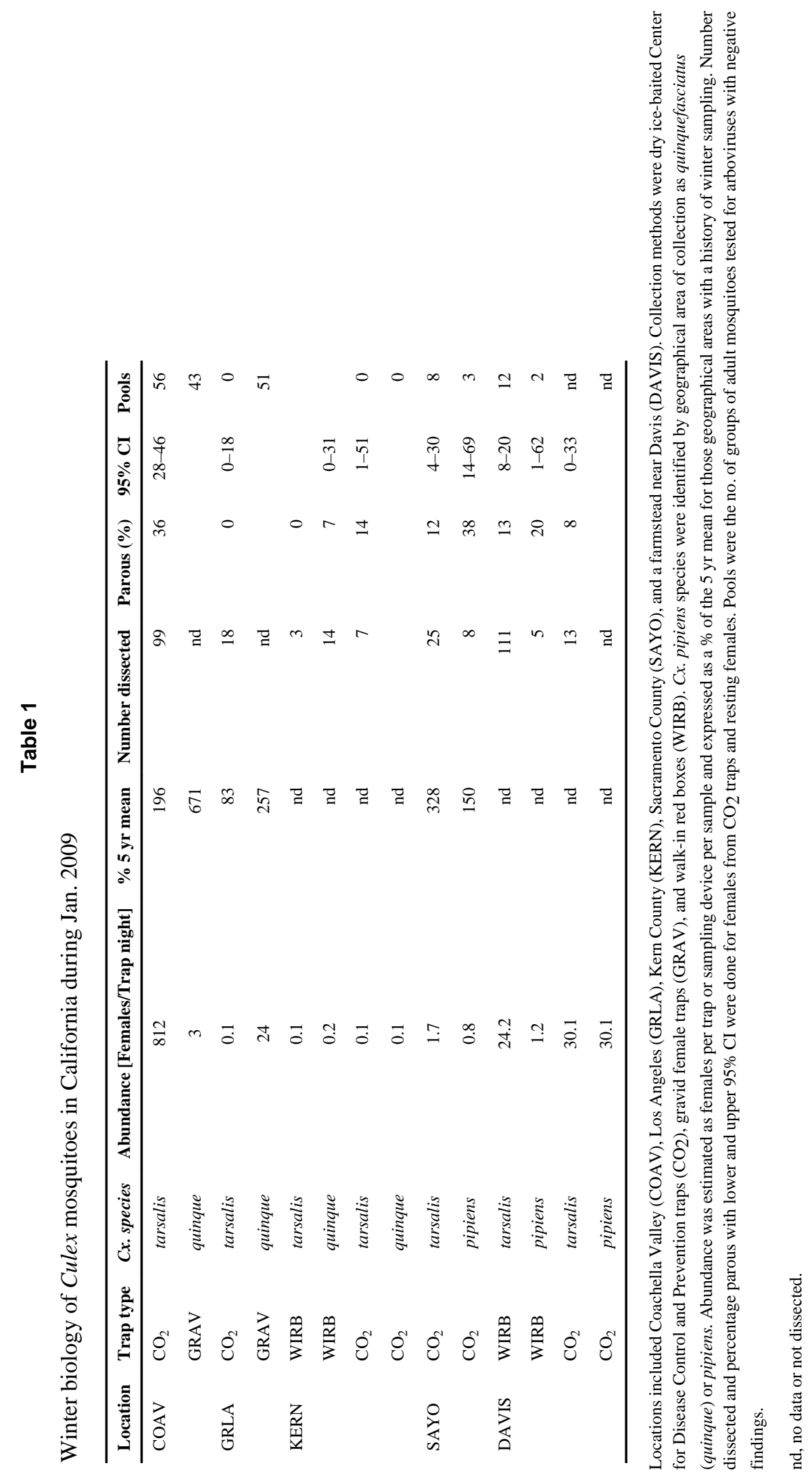

J Med Entomol. Author manuscript; available in PMC 2010 June 11. 